\title{
Influence of brushing on a machined lithium disilicate-based ceramic: assessment of color maintenance and surface roughness
}

\author{
Influência da escovação em uma cerâmica à base de dissilicato de lítio \\ usinada: avaliação da manutenção cromática e rugosidade superficial
}

\author{
Humberto Lago de Castro* \\ Priscilla Cristoforides Pereira** \\ Sabrina Alves Feitosa** \\ Márcia Carneiro Valera*** \\ Maria Amélia Máximo de Araujo ${ }^{* * *}$ \\ Rodrigo Máximo de Araujo ${ }^{* * *}$
}

\begin{abstract}
Objective: To assess the effect of simulated brushing after different treatments in color maintenance and surface roughness of a ceramic. Materials and methods: Thirty lithium disilicate ceramic blocks were obtained, sintered, finished with water abrasive paper grit, and divided into: Group P-polished with diamond-coated silicone tips; Group G- glaze; Group S- pigment layer and glaze. A brushing simulator machine $\left(37^{\circ} \mathrm{C} / 120\right.$ rpm) was used (10,000; 30,000; and 100,000 cycles) and surface roughness analysis was performed before and after this simulation in a rugosimeter (Ra parameters - mean roughness). The samples color were assessed with a spectrophotometer (Easyshade, Vita; parameters $\left.L^{*} a^{*} b^{*}\right)$. Results: Regarding surface roughness, Group $P$ presented statistical difference after 10 years. Group $G$ presented difference for the initial measurement, and after 1 and 3 years. Regarding color, Group P did not vary after 10 years. Group $G$ presented difference for the initial measurement, and after 1 and 3 years; Group $P$ did not vary after brushing, except for 1 and 10 years The initial color of Group G was similar after 1 and 3 years, however, it presented statistical difference after 10 years. Group $S$ presented similar behavior between the initial periods from 1 to 3 years, however, the initial $\Delta E$ differed statistically for 10 years. Group $S$ were shown to be statistically different from others for all periods, ex-
\end{abstract}

cept for $S$ and $P$ in 1 year. Conclusion: It was concluded that Group $P$ did not suffer initial color alteration after simulated brushing, and Group $G$ and $S$ suffered color alteration after 10 years of simulated brushing.

Keywords: Ceramics. Toothbrushing. Surface properties.

\section{Introduction}

Long-lasting esthetics combined with coordinated and quick dental treatment are the features patients most want from private dental clinics. Currently, it is possible to perform extensive rehabilitations in record times with new techniques and materials available, such as the CAD-CAM system, and more recently, the intraoral digital impression-taking systems. Thus, it has become possible to eliminate various clinical and laboratory steps, and even the manufacturing $\operatorname{cost}^{1}$.

Lithium disilicate-based ceramics are the most attractive because they exhibit a translucence and chromatic depth, very similar to those of natural

\footnotetext{
MSc, PhD, Professor, School of Dentistry, Braz Cubas University at Mogi das Cruzes, Brazil.

PhD Student, Department of Dental Materials and Prosthodontics - Univ Estadual Paulista, São Paulo, Brazil.

PhD, Professor, Department of Dentistry - Univ Estadual Paulista, São José dos Campos, São Paulo, Brazil.

PhD, Professor, Department of Dental Materials and Prosthodontics - Univ Estadual Paulista, São Paulo, Brazil.
} 
teeth ${ }^{2}$. This ceramic may be fabricated by injection system and the CAD-CAM system, in which tooth preparation is scanned (intra- or extraorally), restoration is digitally fabricated in a specific program, ceramic is cut by the cutting unit, and taken for sintering afterwards. This system presents ceramic blocks in basic shades, and for esthetics improvement, a "make-up" with pigments and opacifiers may be applied to color-match the restoration ${ }^{3}$.

Fixed partial dentures pressed in a single piece present higher survival rates than those fabricated in two stages (pressed ceramic infrastructure and stratified covering ceramic ${ }^{2,4}$ ), however, they present inferior esthetic qualities and need a layer of pigment on the surface to improve these characteristics. These pigments are applied on the ceramic surface, and vitrification is performed on this layer. This process has been described in literature for years as the most indicated treatment before clinical use in the oral cavity ${ }^{5,6}$.

When pigmenting a prosthetic restoration is required, some problems may arise, since it is known that ceramics get worn during use because of occlusal contacts between tooth and restoration, resulting in ceramic wear capable of exposing the adjacent ceramic and removing the vitreous layer containing the pigments ${ }^{7,8}$.

Studies have investigated the effect of brushing on surface alterations in restorative materials ${ }^{9-12}$, among these, ceramic abrasion as a result of brushing with dentifrices ${ }^{13}$, which may remove the pigmented layer of the restoration and affect the esthetic characteristics, has been studied. This abrasion in anterior teeth is the problem that may possibly alter the esthetic qualities of the restoration, since there is no occlusal contact on the buccal surface.

The aim of this study was to assess the effect of simulated brushing on a machined ceramic, after the processes of vitrification, make-up application and vitrification, and polishing regarding the color maintenance and surface roughness. The hypotheses of this study were as follows: (1) vitrified or polished ceramics would not present changes in color and surface roughness after simulated brushing cycles; (2) ceramics with make-up application and vitrification lose their initial roughness characteristics and chromatic quality after simulated brushing cycles.

\section{Materials and method}

Pre-sintered lithium disilicate glass-ceramic blocks (IPS E-max CAD, Ivoclar Vivadent), were used to obtain 30 blocks $(7.5 \times 7.5 \times 2.5 \mathrm{~mm})$ cut with a precision cutting machine Isomet $^{\mathrm{TM}} 1000$ (Buehler, USA), and crystallized in a specific furnace (Programat P300/G2 ${ }^{\mathrm{TM}}$ - Ivoclar Vivadent AG,
Schaan, Principality of Liechtenstein), according to the cycle recommended by the manufacturer.

The blocks were flattened and finished with water abrasive paper grit 400, 600 and 1200 (3M do Brasil Ltda, Sumaré, SP, Brazil), for 1 minute on each grit.

\section{Experimental Groups}

Blocks were randomly divided into three experimental groups: P- polished; G- glazed; S- shaded. The samples in Group $P$ were polished with diamond-coated silicone tips (Edenta AG, Hauptstrasse, AU/SG, Switzerland) in the following order: $1^{\text {st }}$ Stage- coarse-grained diamond tip; $2^{\text {nd }}$ Stagemedium-grained diamond tip; $3^{\text {rd }}$ Stage- super fine-grained diamond tip. A single operator performed the procedure with the samples held in between fingers under controlled manual pressure, in a standardized finishing time of 10 seconds, developing circular movements at $8.600 \mathrm{rpm}$.

The blocks in Group G were vitrified in a Programat P300/G2 furnace, using Glaze Fluo (Ivoclar Vivadent AG, Schaan, Principality of Liechtenstein), according to the cycle recommended by the manufacturer. Group S received an application of pigment (Shade- Ivoclar Vivadent AG, Schaan, Principality of Liechtenstein) with a paint brush, and was taken to the furnace according to manufacturer's recommendations. Afterwards, these samples also received a layer of vitrification with glaze over the pigmented layer. A trained dental prosthesis technician performed these procedures.

\section{Surface roughness analysis}

Surface roughness was analyzed before and after the periods of simulated brushing $(10,000$; 30,000 ; and 100,000 cycles).

Quantitative surface roughness analysis was performed with the analyzer tip in a Mitutoyo SJ 400 rugosimeter (Mitutoyo, Tokyo, Honshu, Japan) by a single trained examiner, using the following parameter: Ra (mean roughness) - corresponding to the arithmetic mean of absolute values of roughness profile ordinates (peaks and valleys) in relation to the midline, within the measurement run.

To fix the samples during the analyzer tip readings, they were placed on double-sided adhesive tape (Scotch- 3M, Sumaré, SP, Brazil). Three perpendicular measurements were taken on the sample surfaces with a distance of $1 \mathrm{~mm}$ between each measurement. The rugosimeter covered a $3 \mathrm{~mm}$ -long test span. For each sample, a mean value was obtained from three measurements. After this, the arithmetic mean of each group was obtained. 


\section{Simulated brushing}

For simulated brushing, a Brushing Simulator Machine MEV-2T (Odeme, Joaçaba, SC, Brazil) was used (mean temperature of $37{ }^{\circ} \mathrm{C} ; 120$ cycles per minute).

For fixation on the brushing simulator machine, samples were inserted in acrylic resin according to the size of the machine tub. The resin device was adapted to the machine tub that contained the dentifrice/distilled water slurry $(1 / 2: 1)^{14}$.

Bitufo toothbrushes (Clássica/28/Macia - Itupeva, São Paulo, Brazil) were fitted to the simulator, making linear movements under an axial load of 200g. The dentifrice used was Colgate Tripla Ação (Colgate-Palmolive Indústria e Comércio, São Bernardo do Campo, SP, Brazil).

Samples were submitted to 10,000 cycles, which corresponded to approximately one year of brushing ${ }^{15}$, 30,000 cycles, corresponding to three years of brushing, and 100,000 cycles equivalent to 10 years of brushing. Brushes were replaced after every 20,000 cycles. Brushing was simulated in a temperature-controlled environment $\left(37^{\circ} \mathrm{C}\right)$.

\section{Color determination}

Samples were assessed on color with the Easyshade spectrophotometer (Vita Zahnfabrik, Bad Säckingen, Germany), using the parameters $L^{*} a^{*} b^{*}$ ${ }^{16}$. Coordinate $L^{*}$ represents color changes on the black and white scale; $a^{*}$ represents color and saturation on the red-green axis; $b *$ is related to saturation on the blue-yellow axis. Thus, $\mathrm{L}^{*}$ is the "luminosity" factor, while $\mathrm{a}^{*}$ and $\mathrm{b}^{*}$ are the chromatic coordinates that allow numerical definition of color and the differentiation existent between two colors.

Three readings were taken at each point of the sample with the Easyshade spectrophotometer, before and after the periods of brushing.

\section{Results}

\section{Roughness}

Roughness results $(\mathrm{Ra})$ were assessed by the non-parametric Kruskall Wallis method, and Dunn's test (post-test) $(\alpha=0.05)$. The numerical value corresponded to the mean (SD) (Table 1).

Table 1 - Mean and Standard Deviations of Roughness values (Ra)

\begin{tabular}{l|c|c|c|c|c}
\hline \multicolumn{1}{c|}{$\begin{array}{c}\text { TIME/ } \\
\text { TREATMENT }\end{array}$} & INITIAL & 10,000 & 30,000 & 100,000 & $p$ \\
\hline POLISHING & $0.11(0.02) \mathrm{B} \mathrm{c}$ & $0.15(0.03) \mathrm{B} \mathrm{b}$ & $0.13(0.26) \mathrm{B} \mathrm{b}$ & $0.28(0.07) \mathrm{A} \mathrm{b}$ & $p<0.0001$ \\
GLAZE & $0.41(0.11) \mathrm{A} \mathrm{b}$ & $0.28(0.10) \mathrm{B} \mathrm{c}$ & $0.23(0.03) \mathrm{B} \mathrm{c}$ & $0.40(0.09) \mathrm{A} \mathrm{b}$ & $p=0.0006$ \\
SHADE & $1.02(0.26) \mathrm{A} \mathrm{a}$ & $0.96(0.16) \mathrm{A} \mathrm{a}$ & $1.06(0.28) \mathrm{A} \mathrm{a}$ & $0.97(0.23) \mathrm{A} \mathrm{a}$ & $p=0.4267$ \\
$p$ & $p<0.0001$ & $p<0.0001$ & $p<0.0001$ & $p<0.0001$ & \\
\hline
\end{tabular}

*Same capital letters on the same line represent equality

*Same lower case letters in the same column represent equality

The Polished group presented statistical difference in roughness only after 10 years of brushing. Whereas the Glaze group presented difference from the initial measurement after 1 and 3 years, which differed after 10 years as well. The Shade group presented no difference in roughness at all time intervals.

The roughness between the groups in the initial period of the Shade group was higher than that pre- sented by the Glazed and Polished groups. In the periods of 1 and 3 years the Shade group presented higher roughness, followed by Groups Polished and Glazed. Whereas after 10 years, Group Shade differed statistically from the other two groups.

The results of color $(\Delta \mathrm{E})$ were evaluated by the non-parametric Kruskall Wallis method, and Dunn's test (post-test) $(\alpha=0.05)$. The numerical value corresponded to the mean (SD) (Table 2).

Table 2 - Mean and standard deviation of color values $(\Delta E)$.

\begin{tabular}{|c|c|c|c|c|c|}
\hline TIME/TREATMENT & INITIAL & 10,000 & 30,000 & 100,000 & $\mathrm{P}$ \\
\hline POLISHING & 81.97(1.58) AB a & 81.7(1.04) B ab & $82.82(1.31) \mathrm{AB}$ a & $83.45(0.62) \mathrm{A} \mathrm{a}$ & $p=0.0092$ \\
\hline GLAZE & $82.4(1.3) \mathrm{B} \mathrm{a}$ & $82.81(1.61) \mathrm{AB} a$ & $83.80(1.19) \mathrm{AB}$ a & $84.14(0.9) \mathrm{A} a$ & $p=0.0204$ \\
\hline SHADE & $76.3(3.72) \mathrm{B} b$ & $79.8(2.43) \mathrm{AB} b$ & $78.14(1.90) \mathrm{AB} b$ & $80.5(2.26) \mathrm{A} \mathrm{b}$ & $p=0.0146$ \\
\hline$p$ & $p=0.0013$ & $p=0.0130$ & $p=0.0012$ & $p=0.0003$ & \\
\hline
\end{tabular}

${ }^{*}$ Same capital letters on the same line represent equality

*Same lower case letters in the same column represent equality 
For Group $\mathrm{P}$ the $\Delta \mathrm{E}$ values did not vary after the periods of simulated brushing, except for the period relative to 1 and 10 years $\left(81.7 \pm 1.04^{\mathrm{A}}\right.$ and $83.45 \pm 0.62^{\mathrm{B}}$, respectively). In Group $\mathrm{G}$, initial color was similar after 1 and 3 years, however, it presented statistical difference in the period of 10 years of simulated brushing $\left(82.4 \pm 1.3^{\mathrm{B}}\right.$ and $84.14 \pm 0.9^{\mathrm{A}}$, respectively). The samples that received pigment make-up (Group S) presented a similar behavior between the initial periods of 1 and 3 years, however, the initial $\Delta \mathrm{E}\left(76.3 \pm 3.72^{\mathrm{B}}\right)$ differed statistically from the period of 10 years $\left(80.5 \pm 2.26^{\mathrm{A}}\right)$ (Table 2 ).

The values of Group $\mathrm{S}$ were shown to be statistically different $(\mathrm{p}<0.05)$ from those of Groups $\mathrm{P}$ and $\mathrm{G}$ for all the simulated brushing periods (initial, 1 year, 3 years, and 10 years), except for $S$ and $P$ in the period of 1 year $\left(79.8 \pm 2.43^{\mathrm{b}}\right.$ and $81.7 \pm 1.04^{\mathrm{ab}}$, respectively).

\section{Discussion}

Literatures shows articles where the brushing technique has been used to assess wear resistance and color maintenance of different restorative materials ${ }^{15,17}$. The choice of the type of ceramic surface finishing treatment is important, considering the increase in surface roughness due to exposure to dentifrices or even foods and beverages capable of promoting biofilm accumulation, favoring caries recurrence and the development of periodontal disease.

In the oral cavity, restorative materials are subject to the action of various agents that may alter the quality of their surfaces ${ }^{18}$, which makes wear resistance an important physical property ${ }^{19}$. In the present study, the option was taken to reproduce conditions similar to those that occur in vivo, by using a brushing machine, which is an effective method for assessing wear resistance of restorative materials such as: resin composites, glass ionomer cement, ceramics, titanium, gold, amalgam, and acrylic resins ${ }^{15,18,20}$.

The roughness of the Group Shade in the initial period was higher when compared to the values presented by the Glazed and Polished Groups. In the periods of 1 and 3 years, Group Shade presented higher roughness, followed by Groups Polished and Glazed. Whereas after 10 years, Group Shade statistically differed from the other two groups. The Polished group presented statistical difference in roughness only after 10 years of brushing.

When assessing the effect of brushing with different dentifrices on a hybrid composite, Goldstein e Lernet ${ }^{15}$ (1991) showed that the brushing routine and tooth paste used altered the surface topography. Whereas Etman and Woolford ${ }^{8}$ (2010) showed that IPS e.max Press crowns had a clinical performance compatible with that of the Procera AllCeram system and metal ceramic restorations; however, wear resistance of this type of ceramic is higher than that of the Procera AllCeram system, which presented greater wear of the ceramic and antagonist tooth. Heintze et al. ${ }^{21}$ (2010) showed that microhybrid and hybrid composites presented greater surface deterioration when submitted to high loads, whereas ceramic materials (IPS d.SIGN and IPS Empress) showed little or no deterioration over time, regardless of the load applied. Moreover, ceramic materials presented no deterioration after 5 hours of brushing.

When analyzing color results $(\Delta \mathrm{E})$ of Group $\mathrm{P}$, it was shown that there was no statistically significant difference $(p<0.05)$ between the initial period and the simulated brushing cycles (1 year, 3 years, and 10 years). Group S, which received pigmentation on the surface, presented alteration in color values $(\Delta \mathrm{E})$ compared to the other groups (P and $\mathrm{G}$ ), initially and after 3 and 10 years, and showed chromatic difference even after 10 years of brushing. However, in Group S, the initial color showed statistical difference after 10 years of brushing, revealing color change, meaning the loss of optical characteristics of this pigmented ceramic. In a recent study conducted by Etman and Wollford ${ }^{8}$ (2010), lithium disilicate restorations with makeup (painted) maintained the initial color tonalities, with the exception of some points on the occlusal surface, due to wear and loss of finish.

Well-designed in vivo studies with follow up in the long term are required to clinically prove the findings of this study. Thus, the results obtained in this study in a simulated manner (in vitro) cannot be completely generalized to the clinical situation.

\section{Conclusion}

Within the limitations of this study, it may be concluded that polished ceramics do not suffer initial color alteration after periods of simulated brushing, and ceramics that received glaze or pigment suffered color alteration after 10 years of simulated brushing.

\section{Resumo}

Objetivo: Avaliar o efeito da escovação simulada após diferentes tratamentos na manutenção de cor e rugosidade superficial de uma cerâmica. Materiais e método: Trinta blocos de cerâmica de dissilicato de lítio foram obtidos, sinterizados, planificados com lixa d'água e divididos em: Grupo P-polido com pontas de silicone revestidas por diamante; Grupo G- glaze; Grupo S- pigmento e glaze. Uma máquina de escovação (37 $\left.{ }^{\circ} \mathrm{C} / 120 \mathrm{rpm}\right)$ foi utilizada (10.000, 30.000 e 100.000 ciclos) e a análise de rugosidade foi avaliada antes e após a simulação com um rugosimetro (parâmetro Ra - rugosidade média). A cor das amostras foi avaliada com um espectrofotômetro (Easyshade, Vita; parâme- 
tros $\left.L^{*} a^{*} b^{*}\right)$. Resultados: Para a rugosidade superficial, o Grupo P apresentou diferença após 10 anos; Grupo $G$ apresentou diferença para a medida inicial, após 1 e 3 anos. Em relação à cor, o Grupo $P$ não apresentou diferença após 10 anos. Grupo G apresentou diferença para a medida inicial, após 1 e 3 anos; Grupo $P$ não variou após a escovação, exceto 1 a 10 anos. A cor inicial do Grupo $G$ ficou semelhante após 1 a 3 anos, no entanto, apresentou diferença após 10 anos. Grupo $S$ apresentou comportamento similar entre o período inicial, de 1 a 3 anos, contudo, o $\Delta E$ inicial diferiu para 10 anos. Grupo de $S$ foi estatisticamente diferente dos outros para todos os períodos, exceto para $S$ e $P$ em 1 ano. Conclusão: Concluiu-se que o Grupo P não sofreu alteração de cor inicial após escovação e os grupos $G$ e $S$ sofreram alteração de cor após 10 anos de escovação simulada.

Palavras-chave: Cerâmicas. Escovação dentária. Propriedades de superfície.

\section{References}

1. Shahrbaf S, van Noort R, Mirzakouchaki B, Ghassemieh E, Martin N. Fracture strength of machined ceramic crowns as a function of tooth preparation design and the elastic modulus of the cement. Dent Mater 2014; 30(2):234-41.

2. Esquivel-Upshaw JF, Young H, Jones J, Yang M, Anusavice KJ. Four-year clinical performance of a lithium disilicate-based core ceramic for posterior fixed partial dentures. Int $J$ Prosthodont 2008; 21:155-60.

3. Wozniak WT, Siew ED, Lim J, McGill SL, Sabri Z, Moser JB. Color mixing in dental porcelain. Dent Mater 1993; 9(4):22933.

4. Wolfart S, Eschbach S, Scherrer S, Kern M. Clinical outcome of three-unit lithium-disilicate glass-ceramic fixed dental pros- theses: Up to 8 years results. Dent Mater 2009; 25(9):63-71.

5. Barghi N, Lee A, Draughn RA. When to glaze - An electron microscope study. J Prosthet Dent 1976; 35(6):648-53.

6. Goldstein GR, Barnhard BR, Penugonda BJ. Profilometer, SEM, and visual assessment of porcelain polishing methods. J Prosthet Dent 1991; 65(5):627-34.

7. Heintze SD, Cavalleri A, Forjanic M, Zellweger G, Rousson V. Wear of ceramic and antagonist - A systematic evaluation of influencing factors in vitro. Dent Mater 2008; 24(4):433-49.

8. Etman MK, Woolford MJ. Three-year clinical evaluation of two ceramic crown systems: a preliminary study. J Prosthet Dent 2010; 103(2):80-90.

9. Tanoue N, Matsumura H, Atsuta M. Wear and surface roughness of current prosthetic composites after toothbrush/ dentrifice abrasion. J Prosthet Dent 2000; 84(1):93-7.

10. Yesil Duymus Z, Orbak R, Dilsiz A. Abrasion resistance of veneering materials to tooth brushing. Dent Mater J 2003; 22(4):460-6.

11. Wang L, Garcia FC, De Araujo PA, Franco EB, Mondelli RF. Wear resistance of packable resin composites after simulated toothbrushing test. J Esthet Restor Dent 2004; 16(5):303-14.

12. Teixeira EC, Thompson JL, Piascik JR, Thompson JY. In vitro toothbrush-dentifrice abrasion of two restorative composites. J Esthet Restor Dent 2005; 17(3):172-80.
13. Pereira SMB. Efeito da escovação associada à dentifrício branqueador na degradação superficial e formação de biofilme em materiais cerâmicos [Dissertação de Mestrado]. São José dos Campos: Faculdade de Odontologia de São José dos Campos: Universidade Estadual Paulista - UNESP; 2007.

14. Hossain A, Okawa S, Miyakawa O. Surface texture and composition of titanium brushed with toothpaste slurries of different pHs. Dent Mater 2007; 23(2):186-92.

15. Goldstein GR, Lerner T. The effect of toothbrushing on a hybrid composite resin. J Prosthet Dent 1991; 66(4):498-500.

16. Yui KC. Avaliação in vitro da efetividade de associações de agentes clareadores na alteração da cor de dentes manchados por pigmentos sanguíneos [Tese de Doutorado]. São José dos Campos: Faculdade de Odontologia de São José dos Campos, Universidade Estadual Paulista; 2007.

17. Turssi CP, Hara AT, Magalhães CS, Serra MC, Rodrigues ALR. Influence of storage regime prior to abrasion on surface topography of restorative materials. J Biomed Mater Res B Appl Biomater 2003; 65(2):227-32.

18. Heintze SD, Forjanic M. Surface roughness of different dental materials before and after simulated toothbrushing in vitro. Oper Dent 2005; 30(5):617-26.

19. Correr Sobrinho L, Francisco MU, Consani S, Sinhoreti MAC, Consani RLX. Influência da escovação na rugosidade de superfície de materiais restauradores estéticos. Pós-Grad Revista da Faculdade de Odontologia de São José dos Campos $2001 ; 4(1): 47-55$.

20. Amaral CM, Rodrigues JA, Erhardt MC, Araujo MW, Marchi GM, Heymann HO, et al. Effect of whitening dentifrices on the superficial roughness of esthetic restorative materials. J Esthet Restor Dent 2006; 18(2):102-8.

21. Heintze SD, Forjanic M, Ohmiti K, Rousson V. Surface deterioration of dental materials after simulated toothbrushing in relation to brushing time and load. Dent Mater 2010; 26(4):306-19

\section{Corresponding author:}

Humberto Lago de Castro

Av Engenheiro Francisco José Longo, 555 / 1502

12245-000 São José dos Campos / Sao Paulo, Brazil Phone: + 55 (12) 98127-6109

E-mail: lagodecastro@yahoo.com.br

Recebido: 12/11/2013. Aceito: 03/02/2014. 